\title{
Training and business performance: the mediating role of absorptive capacities
}

\author{
Felipe Hernández-Perlines ${ }^{1 *}$, Juan Moreno-García ${ }^{2}$ nd Benito Yáñez-Araque ${ }^{1}$
}

${ }^{*}$ Correspondence: Felipe.

HPerlines@uclm.es

1 Department of Business

Administration, University

of Castilla-La Mancha, Toledo,

Spain

Full list of author information

is available at the end of the

article

\begin{abstract}
Background: Training has been the focus of considerable conceptual and empirical attention but is considered a relevant factor for competitive edge in companies because it has a positive impact on business performance. This study is justified by the need for deeper analysis of the process involving the transfer of training into performance. This paper's originality lies in the implementation of the absorptive capacities approach as an appropriate conceptual framework for designing a model that reflects the connection between training and business performance through absorptive capacities.
\end{abstract}

Results: Based on the above conceptual framework and using the dual methodological implementation, a new method of analyzing the relationship between training and performance was obtained: efforts in training will not lead to performance without the mediation of absorptive.

Conclusions: Training turns into performance if absorptive capacities are involved in this process. The suggested model becomes an appropriate framework for explaining the process of transformation of training into organizational performance, in which absorptive capacities play a key role. The findings obtained can go further owing to fs/ QCA: of the different absorptive capacities, that of exploitation is a necessary condition to achieve better organizational performance. Therefore, training based on absorptive capacity will guide and facilitate the design of appropriate human resource strategies so that training results in improved performance. This conclusion is relevant for the development of a new facet of absorptive capacities by relating it to training and resulting in first-level implications for human resource management.

Keywords: Training, Business performance, Dynamic capabilities, Absorptive capacity, Resource-based view, Mediating effect, PLS-SEM, Fs/QCA

\section{Background}

Training is considered a relevant factor for competitive edge in companies because it has a positive impact on business performance (Alavi and Leidner 2001; Barba-Aragon and Sanz-Valle 2013; Bassi et al. 2002; Bartel 2000; Black and Lynch 1996; Bryan 2006; Hansson 2007). Although training has been the focus of considerable conceptual and empirical attention in the business literature, the process of transforming training into improved business performance remains unclear.

Given the lack of similar studies, this paper seeks to illuminate how training is transformed into improved performance. In this regard, in line with the argument proposed 
by Hernández-Perlines and Yáñez-Araque (2015), the main objective is the implementation of the dynamic capabilities approach as an appropriate conceptual framework for determining the connection between training and business performance through absorptive capacities. From the above conceptual framework and with the implementation of a dual research methodology, partial least squares-structural equation modeling (PLS-SEM) and fuzzy set qualitative comparative analysis (fs/QCA), a significant contribution is achieved: efforts in training will not lead to improved performance without the mediating role of absorptive capacities, with operating capacity as the condition required for this mediating effect.

The literature has extensively analyzed the impact of training on organizational performance: training with performance, training with competitive advantage, training with business requirements, etc. (Hernández-Perlines and Yáñez-Araque 2015). However, some authors argue that, despite the obvious significance of training, which is difficult to refute from any perspective, it does not have the same impact on science or on business practice. In part, the reason is the lack of generally accepted explanatory models and the inability to make rigorous predictions in this regard (Araujo and Guisan 2006). Some authors suggest that absorptive capacity (ACAP) helps explain how the process of transformation of training into organizational performance occurs (Spence 1973, Taubman and Wales 1973) because it is a mediating variable.

The analysis of both training and ACAP can be performed based on resource-based theory (Barney 1991; Grant 1996; Sveiby 1997; Wernerfelt 1984), knowledge management (Kogut and Zander 1992; Nonaka and Takeuchi 1995), intellectual capital (Bueno et al. 2004; Bontis 2001) and the dynamic capabilities approach (Easterby-Smith and Prieto 2008; Teece et al. 1997). This paper aims to integrate them to adequately conceptualize both training and ACAP.

Most studies that analyze the impact of training on business performance (Wright et al. 1994a, b; Kamoche 1996; Mueller 1996; Barney and Wright 1998; Bassi et al. 1998; Lee and Yang 2000; Hitt et al. 2001) are based on the role that it plays in the development of human capital (Becker 1964; Fahy 2000) and in organizational knowledge (Alavi and Leidner 2001; Bollinger and Smith 2001).

As a result, companies may believe that the mere establishment of training may be enough to improve performance, but this is not true because it is not possible to make rigorous predictions in this regard (Araujo and Guisan 2006). In this sense, ACAP is an element that strengthens the relationship between training and business outcomes.

Zahra and George (2002) reconceptualize ACAP as a multidimensional construct that involves the dynamic capability of creating and using knowledge that is related to the company's capability of being competitive. According to these authors, ACAP has four dimensions that are grouped into two types of capacities: potential ACAP (acquisition and assimilation) and performed ACAP (transformation and exploitation).

In the early days of the ACAP concept, the first connection between training and ACAP could already be found. Cohen and Levinthal (1990) stated that "the ACAP concept is better developed by examining the cognitive structures underlying learning"( $\mathrm{p}$. 129) Hernández-Perlines and Yáñez-Araque (2015) undertake a theoretical journey through the chain relationships of different complementary concepts that help 
understand how training has an impact on performance through the ACAP process, further reinforcing the interconnection between training and ACAP.

The literature provides studies that analyze the moderating effect of ACAP: Engelen et al. (2014), between entrepreneurial orientation and the environment; Ahlin et al. (2014), between social networks and innovation; and external knowledge flows (Escribano et al. 2009). On the other hand, other studies analyze the mediating impact of ACAP; these include studies by Aljanabi et al. (2014), between factors of organizational support and technological innovation; Leal-Rodríguez et al. (2014), on innovation performance; Saenz et al. (2014), on buyer-seller relationships; Adisa and Rose (2013), on knowledge transfer; Liu et al. (2013), on information technology capabilities on business outcomes; Zhou and Wu (2010), on technology management capability and new product development services; Chen and Huang (2009), on human resource practices and the results of organizational innovation; and Van den Bosch et al. (1999), on new knowledge and organizational adaptation. All this leads to the primary hypothesis of this work:

$\mathbf{H}_{1}$ ACAP positively mediates the relationship between human resource training and business performance.

Mathieu and Taylor (2006) define mediation as a variable that behaves as a mediator (in our case, ACAP), enhancing or reducing the influence of a precedent variable (in our case, training) on a criterion variable (in our case, organizational performance). Therefore, the mediating effect helps divide the primary hypothesis previously raised into two sub-hypotheses (fuzzy propositions to operationalize them when implementing fs/ QCA).

The first is linked to training with ACAP. It can be stated that the acquisition of new external knowledge precedes ACAP (Van den Bosch et al. 1999; Zahra and George 2002), with training being the input of ACAP (Cohen and Levinthal 1990; Yahya and Goh 2002). On this basis, the following research hypothesis is proposed:

$\mathbf{H}_{2}$ Training has a positive impact on ACAP.

Several studies have focused on business performance as a result of ACAP. Indeed, the empirical results show a significant positive relationship between ACAP and business performance (Bergh and Lim 2008; Jansen et al. 2005; Lane et al. 2006; Mowery et al. 1996; Mukherjee et al. 2000; Todorova and Durisin 2007; Tsai 2001; Yeoh 2009; Zahra and George 2002). Accordingly, we propose the following research hypothesis:

$\mathbf{H}_{3} \quad$ ACAP has a positive impact on performance.

\section{Methods}

This study analyzes the process involving the transfer of training in performance, through consideration of the absorptive capabilities. This paper's originality lies in the implementation of the absorptive capabilities approach as an appropriate conceptual framework for designing a model that reflects the connection between training and business performance through absorptive capacities. 
The proposed model is shown in Fig. 1. This is a structural model, which can be broken down into two: direct model and mediation model.

\section{Sample}

For the sample selection, the database of Spanish companies compiled by SABI (Iberian Balances Analysis System database) was used. This database provides financial and business information of more than 1.3 million Spanish and Portuguese companies. Before the creation of the final questionnaire, a pretest was performed with a group of six companies. The final questionnaire, called STraDyCaF @ (www.stradycaf.org), is a selfadministered questionnaire with Likert scale questions (1-7) and other open-ended questions that are more specific to the semi-structured interview. The survey was distributed and administered between May and December 2014 through a web-based tool, LimeSurvey version $2.05+$. Through this open source web application, designed for developing and managing surveys and populations, the survey and an institutional letter of introduction presenting it were sent to each participant (i.e., CEO, human resources director, head of training) as an email with a personalized link. To encourage participation and improve the response rate, a simple design was provided allowing for responses from mobile devices, in addition to a text to speech assistant, similar to CATI (computer assisted telephone interviewing) systems. A representative sample of Spanish companies was selected on the basis of simple random sampling, including those with 50 workers and not confined to any particular sector. At the end of the process, as shown in Table 1, 112 valid cases were used to analyze the data in PLS-SEM. Regarding the other analysis method, 25 cases were randomly selected within the valid cases.

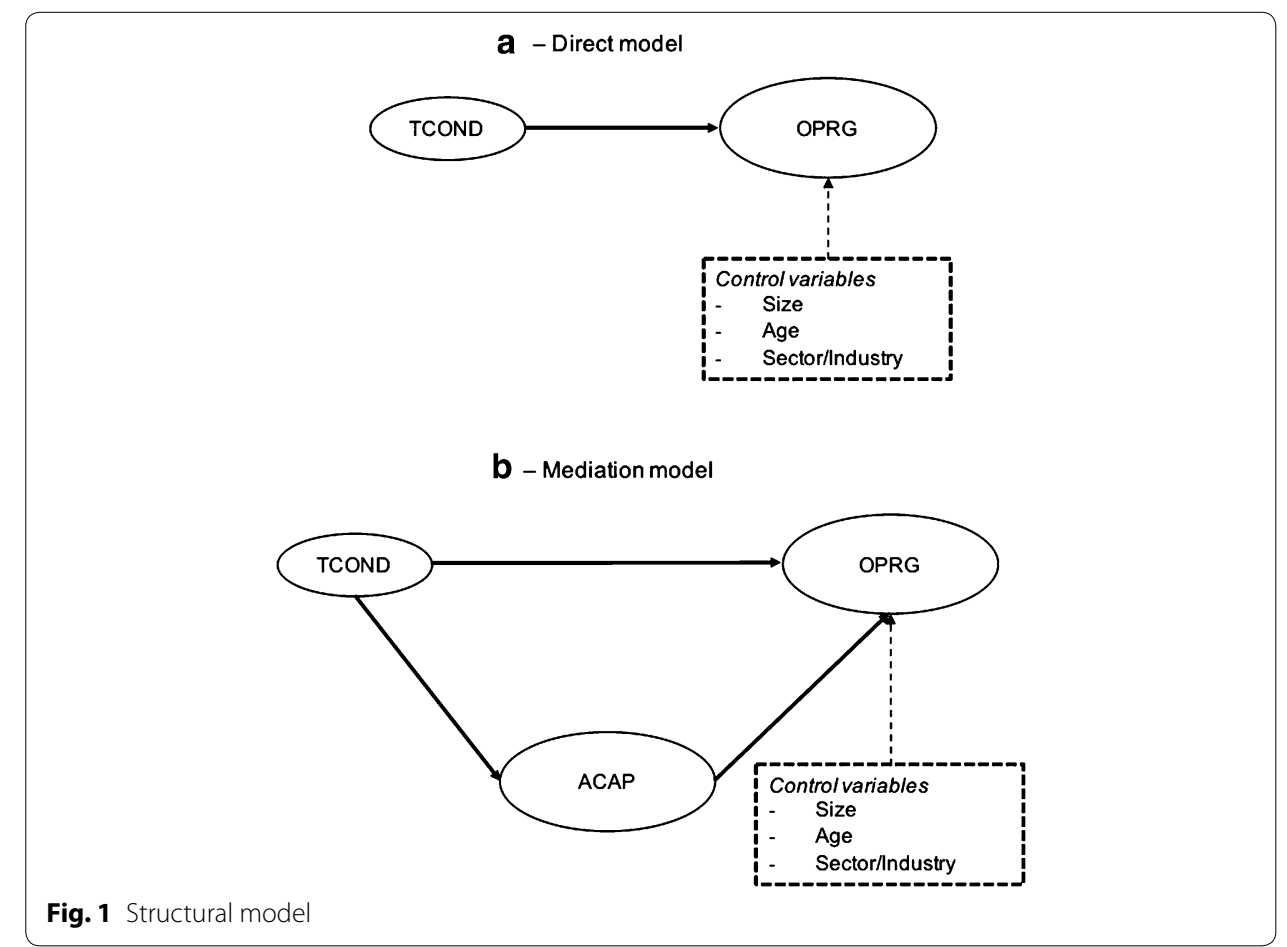


Table 1 Data sheet of the PLS-SEM field and fs/QCA fieldwork

\begin{tabular}{|c|c|}
\hline Target population (universe) & $\begin{array}{l}\text { Spanish companies with } 50 \text { or more workers belonging to any sector } \\
\text { except public administration, the agricultural sector, fishing, activities } \\
\text { of households and extraterritorial bodies }{ }^{a}\end{array}$ \\
\hline Geographical scope & The entire national territory/Spanish national territory \\
\hline Analysis unit/sampling unit & The company \\
\hline Population census ${ }^{b}$ & 22,013 \\
\hline Sample size/response rate (PLS-SEM) & 112 valid surveys $/ 7.18 \%$ \\
\hline Sampling procedure & Simple random sampling without replacement \\
\hline Confidence level & $95 \% ; z=1.96 ; p=q=0.50 ; a=0.05$ \\
\hline Sampling error & $9.24 \%$ \\
\hline Key informant & CEO, head of training and/or human resources director \\
\hline Date of fieldwork/data collection & Between May and December 2014 \\
\hline Sample size (fs/QCA) & Random group of 25 cases from the data set \\
\hline
\end{tabular}

a The excluded economic sectors/activities correspond to the national classification of economic activities (CNAE) 2009 and Statistical Classification of Economic Activities in the European Community (NACE) Rev. 2 sections: (A) agriculture, livestock breeding, forestry and fishing; $(\mathrm{O})$ public administration and defense, compulsory social security; (T) activities of households, such as employers of domestic staff, activities of households, such as producers of goods and services for one's own use; and (U) activities of extraterritorial organizations and bodies

b Source: DIRCE 2014 (Central Companies Directory, Jan 1, 2014)

\section{Measuring variables}

To undertake the study and achieve its purpose, the following three variables were considered: training, absorptive capacities and organizational performance. These variables were measured as described below:

\section{Training}

Training was measured using the validated five-item scale suggested by Castañeda and Fernández (2007), and a Likert scale (1-7) was adopted. In this study, training is considered a first-rate A-type composite for data analysis in PLS.

\section{Organizational performance}

In this study, organizational performance is considered a dependent variable. A Likert scale (1-7), which was validated by Camisón and Villar-López (2010), was used for its measurement. This scale considers two dimensions of organizational performance: first, economic performance (five items) and, second, performance in satisfaction (four items). This variable was considered a second-order A-type composite in PLS.

\section{Absorptive capacity}

The study considers ACAP as a multidimensional variable, in line the suggestions by Cohen and Levinthal (1990) and Lane et al. (2006), by using the four-dimensional scale validated by Flatten et al. (2011), which assesses the extent to which a company is engaged in activities of knowledge acquisition (acquisition, three items), assimilates the acquired information with the existing knowledge (assimilation, four items), transforms the newly adapted knowledge (transformation, four items) and commercially exploits the transformed knowledge to its competitive advantage (exploitation, three items). For all items, a Likert scale (1-7) was used. For the PLS method, absorptive capacity was operationalized as a second-order A-type composite. 


\section{Control variables}

The control variables used in this study were categorical. The main sector of activity, the size measured by the number of workers and the age of the company, i.e., the number of years since its establishment, were considered.

\section{Combination of methods for data analysis}

One of the most significant aspects of this work is the combination of different research methodologies (qualitative and quantitative). In addition to its complementarity, this combination gives validity and robustness to the research conducted (Goertz and Mahoney 2013).

In this paper, we propose two methods. First, the PLS-SEM method is suggested. Nowadays, PLS is an established technique of structural equation analysis, which has been used in a variety of investigations into organization and strategic management (Robins et al. 2002; Tsang 2002). The PLS technique takes a component-based model for estimation of measurement and structural model approach. Its main purpose is the prediction of the dependent variables, and to quantify the direct and indirect effects of variables on each other. This technique is less demanding on the minimum requirements about the sample size, the nature of the measurement scales and the distribution of the observables variables, compared to the tools of structural equation models based on the covariance as LISREL or EQS (Haenlein and Kaplan 2004). PLS path analysis allows to evaluate mediation models and tests mediation hypotheses, using the bootstrapping method (Hayes et al. 2011). As a result, the study uses the bootstrapping method to test mediation, i.e. the importance of indirect effects. Bootstrapping is a nonparametric resampling procedure for the analysis of both simple and multiple mediation. It imposes no assumptions about the distribution of variables or the distribution of the sample and can be applied to small sample sizes with more confidence. Therefore, this approach is perfectly suited for the PLS-SEM method (Hair et al. 2014). Authors like MacKinnon et al. (2004); Hayes and Scharkow (2013) have proven that this method leads to higher performance and higher levels of statistical power than traditional ways of testing mediation hypotheses, such as the Sobel test (1986), which requires a normal distribution of indirect effects in the sample along with other problems that prevent its application with PLS. The PLS-SEM method is particularly interesting in the early stages of theory development (Ringle et al. 2012; Gefen et al. 2011), when researchers include scales that were tested and validated in previous studies or a relatively small sample size (Reinartz et al. 2009), or, finally, when models are very complex (Hair et al. 2014). The PLS-SEM method is not without limitations (e.g., symmetrical causal relationships, net effects, etc.), most frequently due to issues of multiple regression analysis (MRA) and structural equation models (SEMs) (Woodside 2013; Skarmeas et al. 2014). The statistical program SmartPLS 3.2.5 was used to apply PLS-SEM (Ringle et al. 2015).

We propose using fs/QCA, which is suggested to overcome the above constraints. This technique is a useful qualitative method for the study of social phenomena with a small number of data, in which uncertainty can be properly managed (Ragin 2000, 2008). The fs/QCA 2.5 software is used to apply fs/QCA (Ragin and Sean 2014). 


\section{Results}

The results were structured according to the implementation of the various methodologies suggested.

\section{Results for PLS-SEM}

Two distinct stages were developed to interpret and analyze the suggested model in PLSSEM (Barclay et al. 1995): (1) analysis of the measurement model; and (2) analysis of the structural model. This sequence ensures that the suggested measuring scales are valid and reliable.

\section{Analysis of the measurement model}

Table 2 shows the parameters associated with the evaluation of the measurement model. All factor loading values are greater than 0.5, which is considered acceptable by Barclay et al. (1995) and Chin (1998). Additionally, the values of composite reliability and of the average variance extracted (AVE) exceed the recommended limits of 0.7 and 0.5, respectively (Nunnally 1978; Fornell and Larcker 1981). The values obtained support the convergent validity of the A-type composites considered. Finally, to ensure discriminant validity, the correlations between each pair of composites did not exceed the value of the square root value of the AVE of each composite. In addition, following the HTMT criterion (Henseler et al. 2015) all variables achieve discriminant validity (Table 3).

\section{Analysis of the structural model}

Once the convergent and discriminant validity of the measurement model was secured, the relationships between different variables were tested. To determine the different effects, the steps suggested by Hair et al. (2014) were followed to apply the approach by Preacher and Hayes (2004) in the mediation model.

Table 2 Correlation matrix, reliability estimates, convergent and discriminant validity and descriptive statistics

\begin{tabular}{lllllc}
\hline Composite/measures & AVE & $\begin{array}{l}\text { Composite } \\
\text { reliability }\end{array}$ & 1. ACAP & 2. TCOND & 3. ORGP \\
\hline 1. Absorptive capacity (ACAP) & 0.66 & 0.83 & 0.81 & 0 & 0 \\
2. Training conditions (TCOND) & 0.67 & 0.91 & 0.77 & 0.82 & 0 \\
3. Organizational performance (ORGP) & 0.81 & 0.9 & 0.73 & 0.53 & 0.90 \\
Cronbach's alpha & - & - & 0.75 & 0.87 & 0.78 \\
Mean & - & - & 5.04 & 5.32 & 4.90 \\
Typical deviation & - & - & 0.91 & 1.18 & 1.01 \\
\hline
\end{tabular}

The means were evaluated based on the average scores of the different first-order composites that comprise each of the second-order composites considered. The correlations are those of the second-order composites according to the CFA outputs. The elements in the diagonal are the square root of the AVE

Table 3 Heterotrait-monotrait ratio (HTMT)

\begin{tabular}{llll}
\hline & 1. ACAP & 2. TCOND & 3. ORGP \\
\hline 1. Absorptive capacity (ACAP) & & \\
2. Training Conditions (TCOND) & 0.634 & \\
3. Organizational Performance (ORGP) & 0.623 & 0.62 \\
\hline
\end{tabular}


In order to evaluate the statistical significance of path coefficients, standard errors and t-statistics (pseudo-parametric test) are generated from the bootstrapping procedure (5000 subsamples) (Hair et al. 2011). Similarly, the nonparametric approach (not based on any distribution) reports bootstrap confidence intervals of beta weights and indirect effects for mediation hypotheses. According to Henseler et al. (2009): if the confidence interval estimated for the path coefficient does not contain zero, it means that the estimated path coefficient is significantly different from zero, where the percentage (confidence level) is used to calculate confidence intervals. Likewise, the significance of confidence intervals for mediation hypotheses is interpreted, as discussed below. In particular, the percentile approach is applied to the bootstrap re-sampling with a $95 \%$ confidence. The advantage of this approach is that it does not presuppose any distribution of data (Chin 2010).

First, the direct effect between training (TCOND) and organizational performance (ORGP) is observed (model A). To that end, the bootstrap method (5000 sub-samples) is applied. This effect is positive and significant $(\beta=0.572 ; t$ value surpasses the minimum level indicated by Student's t-distribution with one tail and n-1 degrees of freedom, where $\mathrm{n}$ is the number of subsamples with a $99.9 \%$ confidence level. Therefore, the probability of being wrong in rejecting the hypothesis is null: $\mathrm{p}<0.001$. This result is reinforced by applying the percentile method on bootstrap re-sampling in a $95 \%$ confidence interval (Table 4a; Fig. 2a). The second step includes the effect of the mediating variable (ACAP) (model B). The indirect effect is positive and significant (between TCOND and ACAP $\mathrm{H}_{2}: \beta=0.774, \mathrm{p}<0.001$; and between ACAP and ORGP $\mathrm{H}_{3}: \beta=0.797 ; \mathrm{p}<0.001$; confidence intervals does not include zero), with a suppressor effect, which characterizes the sign change of the direct relationship after the mediator variable have been included (Hair et al. 2014) ( $\beta=-0.084 ; \mathrm{p}>0.05$; confidence interval includes zero; not significant) (Table 4b). The explained variance (VAF) is greater than 1 (specifically, 1.16); thus, the direct effect is eliminated. In the model, the positive and significant relationship without the mediating variable becomes negative and not significant after the inclusion of the mediating variable $(\beta=-0.084 ; \mathrm{p}<0.001)$. Therefore, there is full mediation (Baron and Kenny 1986): absorptive capacity fully mediates the relationship between training and organizational performance (hypothesis H1, Fig. 2). In addition, the evaluation of the structural model shows a good fit (GoF: 0.62$)$, high consistency $\left(R_{2}: 0.54\right.$ for model $b$ is still better than model $a$, which is additional support for the mediating role of absorptive capacity), accuracy predictive relevance $\left(\mathrm{Q}_{2}\right.$ : $\mathrm{ACAP} 0.31 ; \mathrm{Q}_{2}$ : ORGP: 0.44): all parameters progressively improve from model A to B: model B is better than Model A. Following Henseler et al. (2014), the standardized root mean square residual (SRMR) for a composite factor model is determined. This provides the exact fit of the composite factor model, thus constituting a confirmatory composite analysis (Felipe et al. 2016). Model A (total effect) achieves a SRMR composite factor model of 0.073, which means an appropriate fit assuming the usual cut-off of 0.08 ( $\mathrm{Hu}$ and Bentler 1999). However, the SRMR composite factor model for Model B is still better: 0.068 . This would imply an additional support for the mediating role of absorptive capacity (Table 5). The analysis of the control variables does not reveal any significant path; therefore, they are excluded from the model. 
Table 4 Causal relationships: total, direct and indirect effects

\begin{tabular}{|c|c|c|c|c|c|c|}
\hline \multirow[t]{2}{*}{ Direct effects } & \multirow[t]{2}{*}{$\begin{array}{l}\text { Path } \\
\text { coefficient ( } \beta \text { ) }\end{array}$} & \multirow[t]{2}{*}{$\begin{array}{l}\text { Point } \\
\text { estimate }\end{array}$} & \multirow[t]{2}{*}{$\begin{array}{l}\mathrm{t} \text {-value } \\
\text { (bootstrap) }\end{array}$} & \multicolumn{2}{|c|}{$\begin{array}{l}\text { Percentile } 95 \% \text { confi- } \\
\text { dence intervals }\end{array}$} & \multirow[t]{2}{*}{ Support } \\
\hline & & & & Lower & Upper & \\
\hline \multicolumn{7}{|c|}{ Total and indirect effects/mediation hypotheses } \\
\hline \multicolumn{7}{|c|}{ (a) Model A (SRMR cfm = 0.073) } \\
\hline $\begin{array}{l}\text { Total effect of Training } \\
\text { on O. Performance (c) } \\
\text { (Model A: model with } \\
\text { total effect) }\end{array}$ & $0.5723^{* * *}$ & & 8.3753 & 0.4439 & 0.7151 & Yes \\
\hline \multicolumn{7}{|c|}{ (b) Model B (SRMR cfm = 0.068) } \\
\hline $\begin{array}{c}\text { Training } \rightarrow \text { O. Perfor- } \\
\text { mance }=c^{\prime} \text { (direct } \\
\text { effect of Training on } \\
\text { O. Performance) }\end{array}$ & $-0.0836^{\mathrm{ns}}$ & & 0.6174 & -0.3278 & 0.2025 & Not \\
\hline $\begin{array}{l}\mathrm{H} 1=\text { Train- } \\
\text { ing } \rightarrow \mathrm{ACAP} \rightarrow \mathrm{O} \text {. Per- } \\
\text { formance }=a_{1} b_{1} \text { (via } \\
\text { ACAP) (total indirect } \\
\text { effect of Training on } \mathrm{O} \text {. } \\
\text { Performance) }\end{array}$ & & 0.6164 & & 0.4659 & 0.7522 & Yes \\
\hline $\begin{array}{l}\mathrm{H} 2=\text { Train- } \\
\quad \text { ing } \rightarrow \text { ACAP }=a_{1}\end{array}$ & $0.7737^{* * *}$ & & 21.4803 & 0.7003 & 0.8416 & Yes \\
\hline $\begin{array}{l}\mathrm{H} 3=\mathrm{ACAP} \rightarrow \mathrm{O} . \\
\quad \text { Performance }=b_{1}\end{array}$ & $0.7967^{* * *}$ & & 7.8783 & 0.5721 & 0.9753 & Yes \\
\hline
\end{tabular}

ACAP absorptive capacity, O. Performance organizational performance

$\mathrm{t}(0.05,4999)=1.645158499, \mathrm{t}(0.01,4999)=2.327094067, \mathrm{t}(0.001,4999)=3.091863446$

*** $p<0.001$, ns not significant (based on $t$ (4999), one-tailed test)

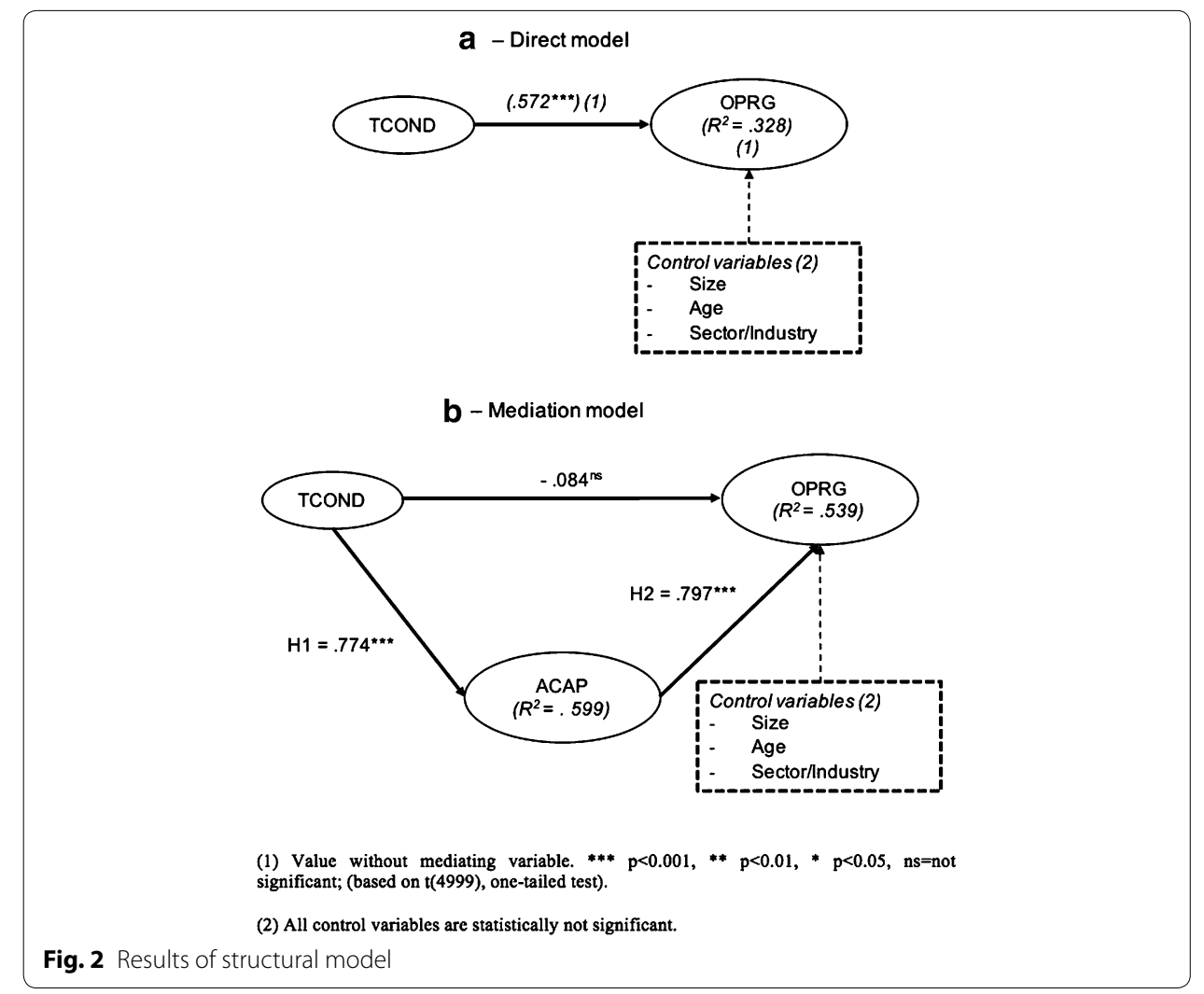


Table 5 Summary of evaluation of the structural models

\begin{tabular}{|c|c|c|c|c|c|c|c|}
\hline $\begin{array}{l}\text { Comparison of mod- } \\
\text { els effects on endogenous } \\
\text { variables }\end{array}$ & $\begin{array}{l}\text { Direct } \\
\text { effects }^{\mathrm{a}}\end{array}$ & $\begin{array}{l}\text { Explained } \\
\text { variance }\end{array}$ & $R^{2}$ value & $\mathrm{Q}^{2}$ value & $\Delta \mathrm{R}^{2}$ & $f^{2}$ & GoF \\
\hline Model A & & & & & & & 0.4900 \\
\hline $\begin{array}{l}\text { Training } \rightarrow \text { O. Perfor- } \\
\text { mance }=c \text { (only direct } \\
\text { effect) }\end{array}$ & Sig. & & 0.3275 & 0.1768 & & & \\
\hline Model B & & & & & & & 0.6241 \\
\hline \multicolumn{8}{|l|}{ Endogenous latent variables } \\
\hline ACAP & & & 0.5987 & 0.3147 & & & \\
\hline $\mathrm{H} 2=$ Training $\rightarrow \mathrm{ACAP}=a_{1}$ & Sig. & 0.5987 & & & & & \\
\hline $\begin{array}{l}\text { O. Performance (mediated } \\
\text { by ACAP) }\end{array}$ & & & 0.5387 & 0.4417 & 0.2112 & 0.4578 & \\
\hline $\begin{aligned} \text { Training } & \rightarrow \text { O. Perfor- } \\
\text { mance } & =c^{\prime}\end{aligned}$ & Nsig. & $0.0445^{b}$ & & & & & \\
\hline $\begin{array}{l}\mathrm{H} 3=\mathrm{ACAP} \rightarrow \text { O. Perfor- } \\
\text { mance }=b_{1}\end{array}$ & Sig. & 0.5832 & & & & & \\
\hline
\end{tabular}

\section{Predictive validity of the PLS model using holdout samples}

Assessment of the model's predictive validity using retention samples completes the PLS-SEM analysis in this study (Becker et al. 2013; Cepeda et al. 2016; Evermann and Tate 2016; Hernández-Perlines 2016). Randomly assigning numbers to cases divides the original sample into two subsamples: the training sample (two-thirds of the total population: 75 cases), and the holdout sample (one-third of the total population: 37 cases). The following steps are the estimation of parameters in the training sample and the standardization of data for each composite in the holdout sample, bearing in mind that absorptive capacity and organizational performance are second-order composites. This step allows the creation of each indicator from a linear combination of its respective composites in the holdout sample, using the weightings from the training sample. In the study applies the new linear combinations to the first-order dimensions and the second-order composites. The second-order composites and the composite training are therefore as follows, with weights obtained from training sample:

$$
\begin{array}{rl}
\text { ACAP }= & 0.232 \mathrm{AC}_{\text {std }}+0.268 \mathrm{AS}_{\text {std }}+0.303 \mathrm{TRANSF}_{\text {std }}+0.451 \mathrm{EX}_{\text {std }} \\
\text { ORGP }= & 0.505 \mathrm{ORGPC}_{\text {std }}+0.647 \mathrm{ORGPS}_{\text {std }} \\
\mathrm{TCOND} & 0.279 \mathrm{TCONDFQ}_{\text {std }}+0.236 \mathrm{TCONDFQ}_{\text {std }}+0.261 \mathrm{TCONDFQ}_{\text {std }} \\
& +0.13 \mathrm{TCONDFQ}_{\text {std }}+0.271 \mathrm{TCONDFQ}_{\text {std }}
\end{array}
$$

The next step consists of standardizing the values of each composite in the holdout sample. The path coefficients of the training sample then serve to complete score prediction for each composite in the holdout sample, thus yielding the following expression:

$$
\mathrm{ORGP}_{\text {pred }}=-0.043 \mathrm{TCOND}_{\text {std }}+0.811 \mathrm{ACAP}_{\text {std }}
$$


For the composite ORGP, $\mathrm{R}^{2}$ is a square correlation of the predicted ORGP and the ORGP in the standardized model.

$$
\mathrm{R}^{2}=\left(\operatorname{corr}\left(\text { ORGP }_{\text {pred }}, \text { ORGP }_{\text {std }}\right)\right)^{2}=0.634
$$

Finally, to complete the assessment of the model's predictive validity, the study compares the $\mathrm{R}^{2}$ for the holdout sample with the $\mathrm{R}^{2}$ for the training sample (to two decimal places).

$$
\begin{aligned}
& \mathrm{R}_{\text {holdoutsample }}^{2}=0.63 \\
& \mathrm{R}_{\text {Trainingsample }}^{2}=0.60
\end{aligned}
$$

The two values are close, thus indicating that the model has predictive validity.

\section{Results for fs/QCA}

Regarding the implementation of this method, first, we calibrate the data. To do so, we use the Calibrate function (var, full, mid, non-full) with values of 7.5 and 3, respectively. Regarding the input condition (exp), the function Expls $=$ Calibrate (exp, 7, 5, 3) is used, with fs being the fuzzy condition (Zadeh 1965; Moreno-Garcia et al. 2014) that is added to the input condition.

The study results applied to hypothesis $\mathrm{H} 2$ show that, in all cases, consistency exceeds the value of 0.65 , i.e., the "usually necessary conditions," becoming "almost always necessary conditions" in the case of the following conditions: condfq2fs, condfq $3 f s$, cond$f q 4 f s$ and condfq5fs, although none of them is individually sufficient. On the other hand, all negated conditions are less than 0.50 , except $\sim$ condfq1fs, which has a value of 0.55 ("more often than unnecessary conditions") (Table 6).

In addition, there is a combination of conditions that guarantee the level of ACAP (Table 7). This combination uses all input combinations, obtaining a strong consistency (0.88, which is higher than the minimum value of 0.75 recommended by Ragin 2008).

\begin{tabular}{|c|c|c|c|c|c|}
\hline \multicolumn{3}{|c|}{$\begin{array}{l}\mathrm{H}_{2}: \text { Analysis of necessary condition } \\
\mathrm{H}_{2} \text { Outcome: ACAP }\end{array}$} & \multicolumn{3}{|c|}{$\begin{array}{l}\mathrm{H}_{3} \text { : Analysis of necessary condition } \\
\mathrm{H}_{3} \text { Outcome: ORGP }\end{array}$} \\
\hline & Consistency & Coverage & & Consistency & Coverage \\
\hline condfq $1 \mathrm{fs}$ & 0.771714 & 0.783151 & adqfs & 0.779099 & 0.715289 \\
\hline condfq2fs & 0.853958 & 0.811541 & asqfs & 0.778250 & 0.728140 \\
\hline condfq3fs & 0.965411 & 0.733645 & transffs & 0.790994 & 0.799142 \\
\hline condfq 4 fs & 0.811683 & 0.764110 & exqfs & 0.951572 & 0.700876 \\
\hline condfa5fs & 0.906995 & 0.685648 & radqfs & 0.592183 & 0.572250 \\
\hline$\sim \operatorname{condfq} 1 \mathrm{fs}$ & 0.551883 & 0.589491 & asqfs & 0.613424 & 0.581320 \\
\hline$\sim$ condfa2fs & 0.486549 & 0.559682 & $\sim$ transffs & 0.586236 & 0.516854 \\
\hline$\sim$ condfa $3 \mathrm{fs}$ & 0.371253 & 0.612944 & exqfs & 0.430756 & 0.562084 \\
\hline$\sim$ condfq 4 fs & 0.492698 & 0.573345 & & & \\
\hline$\sim$ condfq 5 fs & 0.291314 & 0.486521 & & & \\
\hline
\end{tabular}
On the other hand, the coverage value is sufficient (0.69). Moreover, membership values

Table 6 Analysis of the necessary conditions for $\mathrm{H}_{2}$ and $\mathrm{H}_{3}$ 
Table 7 Results when using fs/QCA

\begin{tabular}{|c|c|c|c|}
\hline Causal configuration & Gross coverage & Single coverage & Consistency \\
\hline \multicolumn{4}{|l|}{ Results for $\mathrm{H}_{2}$ complete solution (outcome: ACAP) } \\
\hline condfq $1 \mathrm{fs} \mathrm{s}^{*}$ condfa $2 \mathrm{fs}^{*}{ }^{*}$ condfq $3 \mathrm{fs}^{*}{ }^{*}$ condfq $4 \mathrm{fs} \mathrm{s}^{*}$ condfa $5 \mathrm{fs}$ & 0.694081 & 0.694081 & 0.884427 \\
\hline \multicolumn{4}{|l|}{ Coverage solution: 0.694081} \\
\hline \multicolumn{4}{|l|}{ Consistency solution: 0.884427} \\
\hline \multicolumn{4}{|l|}{ Results for $\mathrm{H}_{3}$ complete solution (outcome: ORGP) } \\
\hline$\sim a s q f s^{*}$ exqfs & 0.570093 & 0.097706 & 0.773933 \\
\hline transffs ${ }^{*}$ exqfs & 0.781648 & 0.309261 & 0.855019 \\
\hline \multicolumn{4}{|l|}{ Coverage solution: 0.879354} \\
\hline Consistency solution: 0.776444 & & & \\
\hline
\end{tabular}

are located in the upper triangle (17 out of 25) (Fig. 3), reflecting that the combination of causal conditions is sufficient to ensure ACAP.

Regarding hypothesis H3 (Tables 6, 7), the same was performed. In this case, the necessary conditions are "usually necessary conditions" for everyone, whereas exqfs has a consistency value of 0.95 , which means that these are "almost always necessary conditions." The negated condition-exqfs has a consistency value of 0.43 , which is not a necessary condition. Therefore, it is a necessary but not sufficient condition to ensure performance. Of the sufficient conditions, two combinations guarantee the level of organizational performance because they have a consistency value of 0.78 (which is greater than the value of 0.75 recommended by Ragin 2008). The coverage value is large (0.88). In addition, the expfs condition is part of both combinations (as assumed in the analysis of the necessary conditions). The consistency of each combination (0.77 and 0.85$)$ is good.

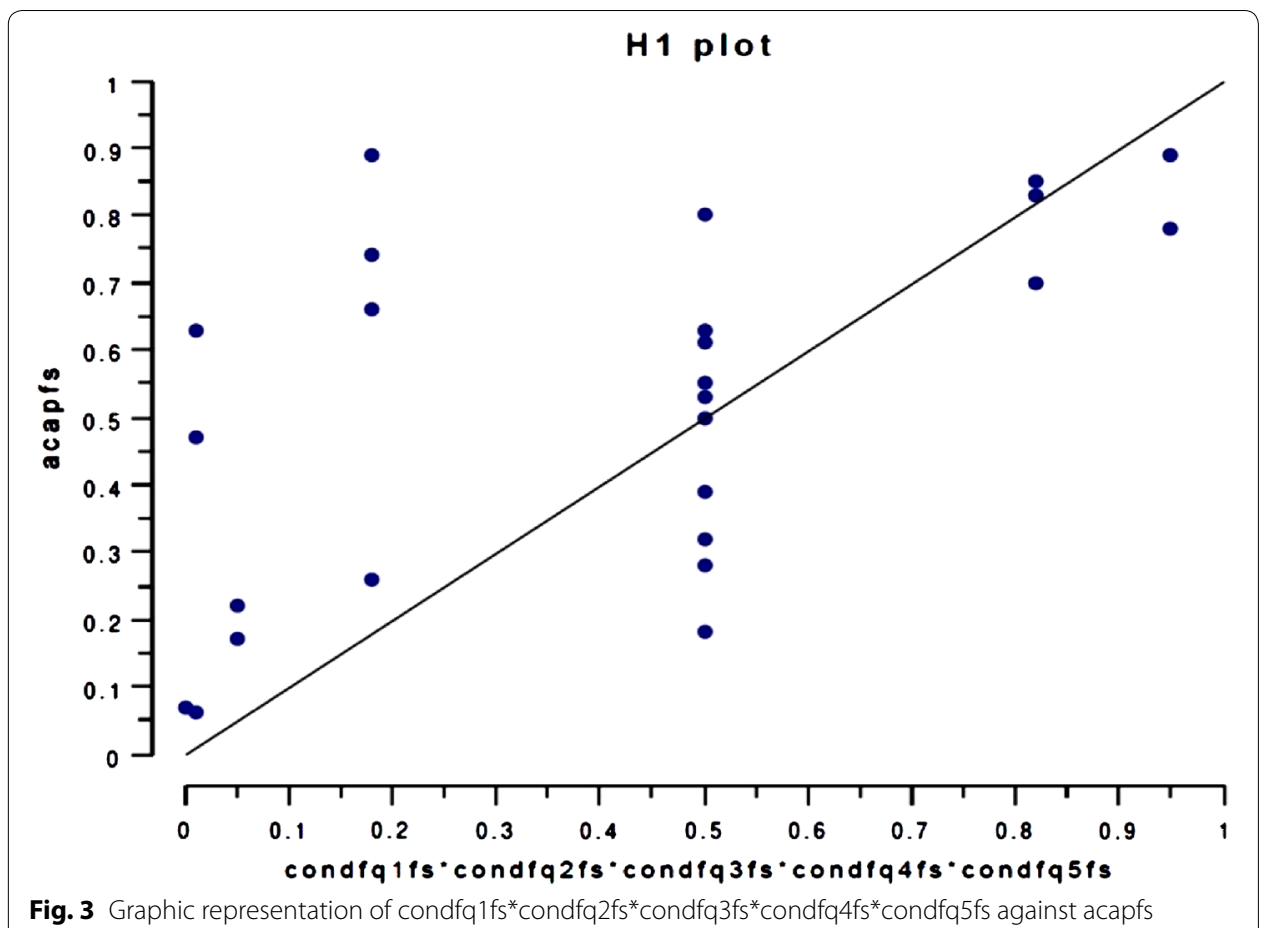


Additionally, in this case, most membership values of the two combinations of causal conditions obtained against the output variable are located in the upper triangle, which reflects that both combinations of causal conditions are sufficient to ensure organizational performance.

\title{
Conclusions
}

This section is structured around the goals outlined in this study. The first major contribution of this paper is of a methodological nature and involves the use of two complementary methodologies in combination: a qualitative methodology and a quantitative methodology. These two methods of data analysis, PLS-SEM and fs/QCA, validate and corroborate the conceptual model proposed.

The most significant conclusion of this study is that training turns into performance if absorptive capacities are involved in this process. The suggested model becomes an appropriate framework for explaining the process of transformation of training into organizational performance, in which absorptive capacities play a full mediation key role.

However the findings obtained can go further owing to fs/QCA: of the different absorptive capacities, that of exploitation is a necessary condition to achieve better organizational performance. Therefore, training based on absorptive capacity will guide and facilitate the design of appropriate human resource strategies so that training results in improved performance.

This paper is relevant for the development of a new facet of absorptive capacities by relating it to training and resulting in first-level implications for human resource management, which, among others, include the following:

a. It is necessary to establish training plans that take into account not only the training requirements but also absorptive capacities.

b. Absorptive capacity appears as a form of appropriation of the performance of the companies' effort in training.

c. Training favors the development of dynamic capacities (Teece et al. 1997) and, in particular, absorptive capacities (Yahya and Goh 2002). Companies must evaluate the different absorptive capacities (especially that of exploitation) and then decide what resources are allocated to these capacities (Brettel et al. 2011).

\begin{abstract}
Abbreviations
ACAP: absorptive capacity; ACAP $_{\text {std: }}$ absorptive capacity standardized; $\mathrm{AC}_{\text {std }}$ : acquisition capacity standardized; $\mathrm{AS}_{\mathrm{std}}$ : assimilation capacity standardized; AVE: average variance extracted; CATI: computer assisted telephone interviewing; CEO: chief executive officer; CNAE: national classification of economic activities; Corr.: correlation; DIRCE: central Companies Directory; EX $_{\text {std }}$ : exploitation capacity standardized; Exp: input condition; fs/QCA: fuzzy set qualitative comparative analysis; HTMT: heterotrait-monotrait ratio of correlations; MRA: multiple regression analysis; Nsig.: nonsignificant; ORGP:

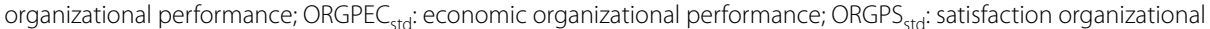
performance; PLS-SEM: partial least squares-structural equation modeling; $R^{2}$ : coeficiente de Pearson; SABI: iberian balances analysis system database; SEMs: structural equation models; Sig.: significant; SRMR: standardized root mean square residual; TRANSF std: $_{\text {: }}$ transformation capacity standardized; TCOND: training conditions; Var.: variable.
\end{abstract}

Authors' contributions

FHP was responsible for the theoretical review and the approach of hypotheses. JMG was responsible for the analysis fs/ QCA BYA was responsible for data collection and SEM-PLS analysis. All authors read and approved the final manuscript.

\section{Author details}

${ }^{1}$ Department of Business Administration, University of Castilla-La Mancha, Toledo, Spain. ${ }^{2}$ Department of Information

Systems and Technologies, University of Castilla-La Mancha, Toledo, Spain. 


\section{Acknowledgements}

The authors thank Ramón Valle and José Luis Roldán for their input and suggestions.

\section{Competing interests}

The authors declares that they have no competing interests.

Received: 28 April 2016 Accepted: 26 November 2016

Published online: 05 December 2016

\section{References}

Adisa F, Rose J (2013) The mediating role of absorptive capacity in knowledge transfer: ERP implementations in small and medium sized enterprises in Sub-Sahara Africa. Int J Enterp Inf Syst 9(2):1-19

Ahlin B, Drnovšek M, Hisrich RD (2014) Exploring the moderating effects of absorptive capacity on the relationship between social networks and innovation. J East Eur Manag Stud 19(2):213-235

Alavi M, Leidner DE (2001) Review: knowledge management and knowledge management systems—conceptual foundations and research issues. MIS Q 25(1):107-136

Aljanabi AQRA, Noor NAM, Kumar DM (2014) The mediating role of absorptive capacity in its effect on organizational support factors and technological innovation. Inf Manag Bus Rev 6(1):25-41

Araujo MB, Guisan A (2006) Five (or so) challenges for species distribution modelling. J Biogeogr 33(10):1677-1688

Barba-Aragon I, Sanz-Valle R (2013) Does training managers pay off? Int J Hum Resour Manag 24(8):1671-1684

Barclay D, Higgins C, Thompson R (1995) The partial least square (PLS) approach to casual modeling: personal computer adoption and use as an illustration. Technol Stud 2(2):285-309

Barney J (1991) Firm resources and sustained competitive advantage. J Manag 17(1):99-120

Barney JB, Wright PM (1998) On becoming a strategic partner: the role of human resources in gaining competitive advantage. Hum Resour Manag 37(1):31-46

Baron RM, Kenny DA, (1986) The moderator-mediator variable distinction in social psychological research: Conceptual, strategic, and statistical considerations. J Pers Soc Psychol 51(6):1173-1182

Bartel AP (2000) Measuring the employer's return on investments in training: evidence from the literature. Ind Relat 39(3):502-524

Bassi LJ, Cheney S, McMurrer D (1998) A common standard for measuring training results. Train Dev 52(3):10-12

Bassi LJ, Ludwig J, McMurrer DP, Buren MV (2002) Profiting from learning: firm-level effects of training investments and market implications. Singap Manag Rev 24(3):61-76

Becker GS (1964) Human capital, 1st edn. Columbia University Press for the National Bureau of Economic Research, New York

Becker JM, Rai A, Rigdon E (2013) Predictive validity and formative measurement in structural equation modeling: embracing practical relevance. In: Abstracts of the thirty tourth international conference on information systems. University Of Milan, Milan, 15-18 Dec 2013

Bergh DD, Lim ENK (2008) Learning how to restructure: absorptive capacity and improvisational views of restructuring actions and performance. Strateg Manag J 29(6):593-616

Black SE, Lynch LM (1996) Human-capital investments and productivity. Am Econ Rev 86(2):263-267

Bollinger AS, Smith RD (2001) Managing organizational knowledge as a strategic asset. J Knowl Manag 5(1):8-18

Bontis N (2001) Assessing knowledge assets: a review of the models used to measure intellectual capital. Int J Manag Rev 3(1):41-60

Brettel M, Greve Gl, Flatten TC (2011) Giving up linearity: absorptive capacity and performance. J Manag Issues 23(2):164-189

Bryan J (2006) Training and performance in small firms. Int Small Bus J 24(6):635-660

Bueno E, Paz Salmador M, Rodríguez O (2004) The role of social capital in today's economy: empirical evidence and proposal of a new model of intellectual capital. J Intellect Cap 5(4):556-574

Camisón C, Villar-López A (2010) An examination of the relationship between manufacturing flexibility and firm performance: The mediating role of innovation. Int J Oper Prod Manage 30(8):853-878

Castañeda DI, Fernández M (2007) From individual learning to organizational learning. Electron J Knowl Manag 5(4):363-372

Cepeda G, Henseler J, Ringle CM, Roldán JL (2016) Prediction-oriented modeling in business research by means of PLS path modeling: introduction to a JBR special section. J Bus Res 69(10):4545-4551

Chen CJ, Huang JW (2009) Strategic human resource practices and innovation performance: The mediating role of knowledge management capacity. J Bus Res 62(1):104-114

Chin WW (1998) The partial least squares approach to structural equation modeling. Mod Methods Bus Res 295(2):295-336

Chin WW (2010) How to write up and report PLS analyses. Springer, Berlin

Cohen WM, Levinthal DA (1990) Absorptive capacity: a new perspective on learning and innovation. Adm Sci Q 35(1):128-152

Easterby-Smith M, Prieto IM (2008) Dynamic capabilities and knowledge management: an integrative role for learning? Br J Manag 19(3):235-249

Engelen A, Kube H, Schmidt S, Flatten TC (2014) Entrepreneurial orientation in turbulent environments: the moderating role of absorptive capacity. Res Policy 43(8):1353-1369

Escribano A, Fosfuri A, Tribó JA (2009) Managing external knowledge flows: the moderating role of absorptive capacity. Res Policy 38(1):96-105 
Evermann J, Tate M (2016) Assessing the predictive performance of structural equation model estimators. J Bus Res 69(10):4565-4582

Fahy J (2000) The resource-based view of the firm: some stumbling-blocks on the road to understanding sustainable competitive advantage. J Eur Ind Train 24(4):94-104

Felipe CM, Roldán JL, Leal-Rodríguez AL (2016) An explanatory and predictive model for organizational agility. J Bus Res 69(10):4624-4631

Flatten TC, Engelen A, Zahra SA, Brettel M (2011) A measure of absorptive capacity: scale development and validation. Eur Manag J 29(2):98-116

Fornell C, Larcker DF (1981) Evaluating structural equation models with unobservable variables and measurement error. J Mark Res 18(1):39

Gefen D, Rigdon EE, Straub D (2011) An update and extension to SEM guidelines for administrative and social science research. MIS Q 35(2):3-14

Goertz G, Mahoney J (2013) Methodological rorschach tests contrasting interpretations in qualitative and quantitative research. Comp Polit Stud 46(2):236-251

Grant RM (1996) Prospering in dynamically-competitive environments: organizational capability as knowledge integration. Organ Sci 7(4):375-387

Haenlein M, Kaplan AM (2004) A beginner's guide to partial least squares analysis. Underst Stat 3(4):283-297

Hair JF, Ringle CM, Sarstedt M (2011) PLS-SEM: indeed a silver bullet. J Mark Theory Pract 19(2):139-151

Hair JF, Hult GTM, Ringle CM, Sarstedt M (2014) A primer on partial least squares structural equation modeling (PLS-SEM) Sage, Thousand Oaks

Hansson B (2007) Company-based determinants of training and the impact of training on company performance. Pers $\operatorname{Rev}$ 36(2):311-331

Hayes AF, Scharkow M (2013) The relative trustworthiness of inferential tests of the indirect effect in statistical mediation analysis: does method really matter? Psychol Sci 24(10):1918-1927

Hayes AF, Preacher KJ, Myers TA (2011) Mediation and the estimation of indirect effects in political communication research. In: Bucy EP, Holbert RL (eds) The sourcebook for political communication research: methods, measures, and analytical techniques. Routledge, New York, pp 434-465

Henseler J, Ringle CM, Sinkovics RR (2009) The use of partial least squares path modeling in international marketing. In: New challenges to international marketing, vol 20. Emerald Group Publishing Limited, pp 277-319

Henseler J, Dijkstra TK, Sarstedt M, Ringle CM, Diamantopoulos A, Straub DW, Calantone RJ (2014) Common Beliefs and Reality About PLS Comments on Rönkkö and Evermann (2013). Organ Res Methods 17(2):182-209

Henseler J, Ringle CM, Sarstedt M (2015) A new criterion for assessing discriminant validity in variance-based structural equation modeling. J Acad Mark Sci 43(1):115-135

Hernández-Perlines F (2016) Entrepreneurial orientation in hotel industry: multi-group analysis of quality certification. J Bus Res 69(2016):4714-4724

Hernández-Perlines F, Yáñez-Araque B (2015) Linking training to organizational performance: an Absorptive capacitybased view. case study method in spanish family businesses. J Promot Manag 21(4):432-446

Hitt MA, Biermant L, Shimizu K, Kochhar R (2001) Direct and moderating effects of human capital on strategy and performance in professional service firms: a resource-based perspective. Acad Manag J 44(1):13-28

Hu LT, Bentler PM (1999) Cutoff criteria for fit indexes in covariance structure analysis: conventional criteria versus new alternatives. Struct Equ Model: Multidiscip J 6(1):1-55

Jansen JJP, Van den Bosch FAJ, Volberda HW (2005) Managing potential and realized absorptive capacity: how do organizational antecedents matter? Acad Manag J 48(6):999-1015

Kamoche K (1996) Strategic human resource management within a resource-capability view of the firm. J Manag Stud 33(2):213-233

Kogut B, Zander U (1992) Knowledge of the firm, combinative capabilities, and the replication of technology. Organ Sci 3(3):383-397

Lane PJ, Koka BR, Pathak S (2006) The reification of absorptive capacity: a critical review and rejuvenation of the construct. Acad Manag Rev 31(4):833-863

Leal-Rodríguez AL, Roldán JL, Ariza-Montes JA, Leal-Millán A (2014) From potential absorptive capacity to innovation outcomes in project teams: the conditional mediating role of the realized absorptive capacity in a relational learning context. Int J Project Manag 32(6):894-907

Lee CC, Yang J (2000) Knowledge value chain. J Manag Dev 19(9/10):783-793

Liu H, Ke W, Wei KK, Hua Z (2013) The impact of IT capabilities on firm performance: the mediating roles of absorptive capacity and supply chain agility. Decis Support Syst 54(3):1452-1462

MacKinnon DP, Lockwood CM, Williams J (2004) Confidence limits for the indirect effect: distribution of the product and resampling methods. Multivar Behav Res 39(1):99-128

Mathieu JE, Taylor SR (2006) Clarifying conditions and decision points for mediational type inferences in organizational behavior. J Organ Behav 27(8):1031-1056

Menard S (2009) Logistic regression: from introductory to advanced concepts and applications. Sage Publications, Beverley Hills

Moreno-Garcia M, Rodriguez-Benitez L, Giralt J, Castillo E (2014) The generation of qualitative descriptions of multivariate time series using fuzzy logic. Appl Soft Comput 23:546-555

Mowery DC, Oxley JE, Silverman BS (1996) Strategic alliances and interfirm knowledge transfer. Strateg Manag J 17:77-91

Mueller F (1996) Human resources as strategic assets: an evolutionary resource-based theory. J Manag Stud 33(6):757-785

Mukherjee A, Mitchell W, Talbot FB (2000) The impact of new manufacturing requirements on production line productivity and quality at a focused factory. J Oper Manag 18(2):139-168

Nonaka I, Takeuchi H (1995) The knowledge-creating company: how Japanese companies create the dynamics of innovation. Oxford University Press, Oxford

Nunnally JC (1978) Psychometric theory. McGraw-Hill, New York 
Preacher KJ, Hayes AF (2004) SPSS and SAS procedures for estimating indirect effects in simple mediation models. Behav Res Methods Instrum Comput 36(4):717-731

Ragin CC (2000) Fuzzy-set social science. University of Chicago Press, Chicago

Ragin CC (2008) Redesigning social inquiry: fuzzy sets and beyond. University of Chicago Press, Chicago

Ragin CC, Sean D (2014) Fuzzy-set/qualitative comparative analysis 2.5. Department of Sociology, University of California, Irvine, California

Reinartz W, Haenlein M, Henseler J (2009) An empirical comparison of the efficacy of covariance-based and variancebased SEM. Int J Res Mark 26(4):332-344

Ringle CM, Sarstedt M, Straub D (2012) A critical look at the use of PLS-SEM in MIS quarterly. MIS Q 36(1):3-14

Ringle CM, Wende S, Becker JM (2015) SmartPLS 3. Hamburg: SmartPLS. Retrieved from http://www.smartpls.com

Robins JA, Tallman S, Fladmoe-Lindquist K (2002) Autonomy and dependence of international cooperative ventures: an exploration of the strategic performance of US ventures in Mexico. Strateg Manag J 23(10):881-901

Saenz MJ, Revilla E, Knoppen D (2014) Absorptive Capacity in Buyer-supplier Relationships: empirical evidence of its mediating role. J Supply Chain Manag 50(2):18-40

Skarmeas D, Leonidou CN, Saridakis C (2014) Examining the role of CSR skepticism using fuzzy-set qualitative comparative analysis. J Bus Res 67(9):1796-1805

Sobel ME (1986) Some new results on indirect effects and their standard errors in covariance structure models. Sociological methodology. American Sociological Association, Washington, pp 159-186

Spence M (1973) Job market signaling. Q J Econ 87(3):355-374

Sveiby KARL (1997) The intangible assets monitor. J Hum Resour Cost Account 2(1):73-97

Taubman PJ, Wales TJ (1973) Higher education, mental ability, and screening. J Polit Econ 81(1):28-55

Teece DJ, Pisano G, Shuen A (1997) Dynamic capabilities and strategic management. Strateg Manag J 18(7):509-533

Todorova G, Durisin B (2007) Absorptive capacity: valuing a reconceptualization. Acad Manag Rev 32(3):774-786

Tsai W (2001) Knowledge transfer in intraorganizational networks: effects of network position and absorptive capacity on business unit innovation and performance. Acad Manag J 44(5):996-1004

Tsang EWK (2002) Acquiring knowledge by foreign partners from international joint ventures in a transition economy: learning-by-doing and learning myopia. Strateg Manag J 23(9):835-854

Van den Bosch FAJ, Volberda HW, De Boer M (1999) Coevolution of firm absorptive capacity and knowledge environment: organizational forms and combinative capabilities. Organ Sci 10(5):551-568

Wernerfelt B (1984) A resource-based view of the firm. Strateg Manag J 5(2):171-180

Woodside AG (2013) Moving beyond multiple regression analysis to algorithms: calling for adoption of a paradigm shift from symmetric to asymmetric thinking in data analysis and crafting theory. J Bus Res 66(4):463-472

Wright PM, McMahan GC, McWilliams A (1994a) Human resources and sustained competitive advantage: a resourcebased perspective. Int J Hum Resour Manag 5(2):301-326

Wright PM, McMahan GC, McWilliams A (1994b) Human resources and sustained competitive advantage: a resourcebased perspective. Int J Hum Resour Manag 5(2):301-326

Yahya S, Goh WK (2002) Managing human resources toward achieving knowledge management. J Knowl Manag 6(5):457-468

Yeoh PL (2009) Realized and potential absorptive capacity: understanding their antecedents and performance in the sourcing context. J Mark Theory Pract 17(1):21-36

Zadeh LA (1965) Fuzzy sets. Inf Control 8(3):338-353

Zahra SA, George G (2002) Absorptive capacity: a review, reconceptualization and extension. Acad Manag Rev 27(2):185-203

Zhou KZ, Wu F (2010) Technological capability, strategic flexibility, and product innovation. Strateg Manag J $31(5): 547-561$

\section{Submit your manuscript to a SpringerOpen ${ }^{\circ}$ journal and benefit from:}

- Convenient online submission

- Rigorous peer review

- Immediate publication on acceptance

Open access: articles freely available online

- High visibility within the field

- Retaining the copyright to your article

Submit your next manuscript at $\boldsymbol{\nabla}$ springeropen.com 